\title{
PENGGUNAAN MEDIA AUDIO UNTUK MENINGKATKAN KEMAMPUAN MENYIMAK CERITA RAKYAT PADA PADA MATA PELAJARAN BAHASA INDONESIA KELAS V SD NEGERI LENGKONG
}

\author{
${ }^{1}$ Ika Maryanti \\ 2Prof. Dr. Mukhidin, ST., M.Pd \\ ${ }^{1}$ Mahasiswa UPI \\ ${ }^{2}$ Dosen UPI \\ 2mukhidin@upi.edu
}

\begin{abstract}
This study aims to determine the improvement of listening ability in grade $V$ students in Lengkong State Elementary School using audio media. The type of research used is a case study with Classroom Action Research (collaborative Classroom Action). The form of collaborative classroom action research with colleagues as observers. The subject of this research is the students of grade $V$ of State Elementary School Lengkong which amounted to 18 people. The object of this research is the ability to listen to folklore. The research design used was Kemmis and Mc. Taggart. Data collection methods used in this study are: 1) test, 2) observation, and 3) field notes. Data analysis technique is done descriptively qualitative. The results showed that learning to listen to folklore using audio media can improve the ability of listening to folklore. Based on the results of the pretest cycle 1 students on average get the score of listening ability to students in the first cycle, the students get an average score of 50, then on cycle II score The average class increased to 87.5, this shows there is an increase in listening ability in grade $V$ students on the material Responding to events that occur around orally.
\end{abstract}

Keywords: Listening to Folklore, Indonesian Lesson

\begin{abstract}
ABSTRAK
Penelitian ini bertujuan untuk mengetahui peningkatan kemampuan menyimak pada siswa kelas $\mathrm{V}$ di Sekolah Dasar Negeri Lengkong menggunakan media audio. Jenis penelitian yang digunakan adalah Penelitian Studi kasus dengan Tindakan Kelas (Classroom Action Research ) kolaboratif. Bentuknya penelitian tindakan kelas yang bersifat kolaboratif dengan rekan sejawat sebagai observer. Subjek peneltian ini adalah siswa kelas V SD Negeri Lengkong yang berjumlah 18 orang. Objek dalam penelitian ini adalah kemampuan menyimak cerita rakyat. Desain penelitian yang digunakan adalah Kemmis dan Mc.Taggart . Metode pengumpulan data yang digunakan dalam penelitian ini adalah : 1) tes, 2) observasi, dan 3) catatan lapangan. Teknik analisis data dilakukan secara deskriptif kualitatif. Hasil
\end{abstract}


penelitian menunjukan bahwa pembelajaran menyimak cerita rakyat menggunakan media audio dapat meningkatkan kemampuan menyimak cerita rakyat .Berdasarkan hasil pretest siklus 1 siswa rata-rata memperoleh skor kemampuan menyimak terhadap siswa pada siklus I, siswa memperoleh skor rata-rata 50, kemudian pada siklus II skor rata-rata kelas meningkat menjadi 87,5,hal ini menunjukan terdapat peningkatan kemampuan menyimak pada siswa kelas $\mathrm{V}$ pada materi Menanggapi peristiwa yang terjadi di sekitar secara lisan.

Kata Kunci : Menyimak Cerita Rakyat, Pelajaran Bahasa Indonesia

\section{A. PENDAHULUAN}

Dalam mata pelajaran Bahasa Indonesia terdapat empat keterampilan berbahasa, yaitu keterampilan menyimak, berbicara, membaca dan menulis. Dari empat keterampilan berbahasa tersebut dapat digolongkan menjadi dua kelompok besar yaitu keterampilan yang bersifat menerima (represif) meliputi keterampilan menyimak dan membaca serta keterampilan yang bersifat mengungkapkan (produktif) meliputi keterampilan menulis dan berbicara.

Apabila dikaitkan antara keterampilan berbahasa tersebut dengan tujuan pembelajaran, pada dasarnya keempat keterampilan tersebut merupakan tujuan yang ingin dicapai dalam pembelajaran Bahasa Indonesia. Pembelajaran Bahasa Indonesia pada hakikatnya diarahkan untuk meningkatkan kemampuan siswa dalam berkomunikasi, baik secara lisan maupun tulisan, serta menumbuhkan apresiasi terhadap hasil karya sastra. Selain itu, tujuan pembelajaran Bahasa Indonesia adalah untuk mengembangkan kemampuan bahasa dalam segala fungsinya, yaitu sebagai sarana komunikasi, sarana berfikir, sarana mengemukakan gagasan/ide, 
perasaan, dan sebagai sarana

berekpresi.

Menyimak sebagai salah satu

keterampilan berbahasa menjadi

dasar keterampilan berbahasa

lainnya karena penguasaan

keterampilan

menyimak

merupakan kegiatan pertama yang

dikuasai manusia dan kegiatan

yang banyak dilakukan dari

kegiatan berbahasa yang lainnya.

Dengan kata lain menyimak

merupakan suatu proses,

sebagaimana Tarigan (Djuanda,

2008: 12)

Dalam kegiatan sehari hari, menyimak adalah salah satu kegiatan yang sangat penting dibandingkan keterampilan lain. Hal ini disebabkan menyimak termasuk keterampilan awal yang terlebih dahulu dilaksanakan dibandingkan berbicara, membaca, dan menulis.
Menyimak

merupakan

kemampuan dasar yang harus

dikuasai oleh seseorang.

Kemampuan menyimak dapat

menentukan keberhasilannya, jika

seseorang tersebut dapat

menguasai informasi yang telah

disampaikan. Tidak semua orang

memiliki kemampuan menyimak

yang baik dalam menerima

informasi. Seseorang tidak akan dapat menerima informasi yang jelas, baik,dan benar jika kemampuan menyimaknya kurang baik. Oleh sebab itu, ilmu pengetahuan dalam menyimak merupakan syarat untuk mencapai keberhasilan dalam menyampaikan informasi kepada orang lain agar seseorang yang menyimak tidak salah dengan informasi yang diterima.

Seseorang akan merespon dan menanggapi kata yang telah 
Didaktik : Jurnal Pendidikan Guru Sekolah Dasar, ISSN : 24775673

Sekolah Tinggi Keguruan dan IImu Pendidikan Subang Volume II Nomor 2, Juli 2017

disampaikan kemudian akan kemampuan menyimak yang

memahaminya berdasarkan berbeda-beda. Ada siswa yang

pengetahuan yang telah diperoleh. cepat dalam menyimak, dan ada

Kemampuan menyimak lebih juga siswa yang lambat menyimak.

banyak dilakukan siswa Siswa tidak akan dapat menangkap

dibandingkan keterampilan bahasa informasi atau pelajaran apabila

lainnya seperti berbicara, siswa tersebut tidak memiliki

membaca, dan menulis. kemampuan menyimak yang baik.

Sehubungan ini, Rankin dalam Penyimak yang baik yaitu penyimak

Slamet (2012:12) menyatakan yang dapat memusatkan pikiran

bahwa umumnya setiap hari orang dan perhatiannya pada apa yang

menghabiskan waktunya untuk akan disimak.

menyimak 45\%, untuk berbicara

Untuk mengembangkan

$30 \%$, untuk membaca $16 \%$, dan kemampuan menyimak, siswaa kan

hanya $9 \%$ untuk menulis. diarahkan pada peningkatan daya

Berdasarkan pernyataan tersebut simaknya melalui pembelajaran

dapat dikemukakan bahwa menyimak. Pada pembelajaran

kemampuan menyimak harus menyimak ini siswaakan dilatih

dibina dan ditingkatkan, karena kemampuan menyimaknya melalui

sangat dibutuhkan oleh siswa SD bahan simakan.

khususnya pada saat proses Cerita rakyat merupakan pembelajaran.

cerita yang sudah ada sejak zaman

Dalam proses pembelajaran dahulu dan telah berkembang serta

menyimak, siswa memiliki dikenal oleh rakyat atau 
masyarakat. Cerita rakyat ini tersebar di masyarakat secara lisan atau dari mulut ke mulut. Cerita rakyat akan lebih menarik apabila disampaikan atau diceritakan secara langsung dan melalui media audio (rekaman).

Dalam perkembangan ilmu pengetahuan dan teknologi, menuntut untuk mampu menyimak berbagai informasi dengan cepat dan tepat, seperti melalui media rekaman. Oleh sebab itu, saat pembelajaran bahasa khususnya menyimak tidak hanya dilakukan melalui tatap muka, tetapi dapat dilakukan dengan menggunakan media yang dapat menunjang pembelajaran di sekolah misalnya media audio (rekaman).

\section{B. METODE PENELITIAN}

Jenis penelitian ini adalah Penelitian Tindakan Kelas
(Classroom Action Research). PTK adalah penelitian yang dilaksanakan oleh guru di dalam kelas. Kelas maksudnya bukanlah wujud ruangan, tetapi sekelompok peserta didik yang sedang belajar. Dengan demikian, penelitian tindakan kelas dapat dilakukan tidak hanya di ruang kelas, tetapi dimana saja tempatnya, yang penting sekelompok anak yang sedang belajar. Penelitian tindakan pada hakikatnya merupakan rangkaian "Riset-tindakan-risettindakan dan seterusnya yang dilakukan secara siklik dalam rangka memecahkan masalah, sampai masalah itu terpecahkan (Ekawarna, 2010: 15).

\section{HASIL PENELITIAN}

Dalam penelitian tindakan kelas ini, akan dikemukakan mengenai beberapa hal, adapun beberapa hal tersebut adalah kondisi awal menyimak cerita, perencanaan, pelaksanaan, refleksi pada setiap siklus dan hasil tes menyimak cerita, observasi pembelajaran menyimak cerita rakyat serta penggunaan 
media audio dalam pembelajaran menyimak cerita rakyat.

Dalam penelitian ini, setiap siklus terdiri dari dua pertemuan. Setiap siklus direncanakan, kemudian dilaksanakan sesuai dengan rencana pelaksanaan serta dilakukannya sebuah pengamatan untuk mengetahui kendala yang ada pada pelaksanaan. Setelah melakukan pengamatan, tahap selanjutnya adalah refleksi.

\section{Deskripsi}

Kemampuan

\section{Menyimak Cerita Siswa Kelas}

\section{V pada pra siklus}

Peneliti melakukan kegiatan prasiklus sebagai acuan untuk mengetahui kondisi awal siswa. Prasiklus ditujukan pada hasil pembelajaran kemampuan menyimak cerita rakyat siswa kelas V SD Negeri Lengkong kecamatan Cipeundey, kabupaten Subang. Hasil dari kegiatan pra siklus digunakan untuk menentukan tindakan yang akan dilaksanakan ketika penelitian. Peneliti melakukan diskusi dengan guru kelas $\mathrm{V}$ kemudian bersama-sama menyusun
Rencana

Pelaksanaan

Pembelajaran (RPP) untuk kegiatan siklus 1. Penelitian ini dilaksanakan pada hari Jum'at, 11 Agustus 2017 pukul 07.45-09.00 WIB. Kegiatan pada prasiklus dilakukan dengan meminta siswa untuk menyimak cerita rakyat setelah guru memberikan materi pembelajaran. Dalam prasiklus kegiatan pembelajaran belum menggunakan media audio (jenis rekaman), hal ini bertujuan untuk mengetahui kondisi kemampuan awal siswa dalam menyimak cerita tanpa menggunakan media audio.

\section{a. Data observasi pada tahap prasiklus}

Pembelajaran pada prasiklus, siswa kurang antusias mengikuti pembelajaran yang akan dilakukan. Siswa tidak siap untuk belajar, hal ini dibuktikan siswa berbicara dengan siswa lain ketika guru masuk ke kelasdan suasana kelas sangat ramai. Guru berulang kali harus meminta siswa untuk tenang dan mempersiapkan diri untuk belajar. Ketika guru membacakan sebuah cerita, banyak siswa 
berbicara sendiri atau bermain sendiri sehingga guru harus mengingatkan anak-anak untuk menyimak lebih serius. Hal ini menyebabkan informasi yang diperoleh hanya sepenggalsepenggal dan tidak koherensi. Ketika siswa diminta untuk untuk mengerjakan LKS, hanya beberapa siswa yang mengerjakan dengan sungguhsungguh. Kemudian guru harus menunjuk salah satu siswa untuk maju membacakan hasilnya, karena tidak ada yang berani maju ke depan. Ketika diminta untuk mengutarakan hasil yang berbeda atau pertanyaan bila kurang jelas, siswa hanya diam saja.

\section{b. Hasil pra-siklus}

Kemampuan awal menyimak cerita rakyat siswa kelas $\mathrm{V} S \mathrm{SD}$ Negeri Lengkong diketahui dari hasil post-test pada tahap prasiklus. Hasil menyimak cerita rakyat siswa pada pra-siklus dinilai berdasarkan ketepatan jawaban siswa terhadap soal yang diberikan.
2. Deskripsi

Kemampuan

Menyimak Cerita Rakyat Siswa Kelas V pada Siklus I

\section{a. Perencanaan}

Data yang diperoleh pada tahap pra-siklus dijadikan sebagai acuan dalam melaksanakan tindakan pada siklus pertama, dengan tujuan agar diperoleh suatu peningkatan proses dan hasil kemampuan menyimak cerita rakyat siswa pada mata pelajaran Bahasa Indonesia. Pada tahap perencanaan, peneliti menyusun rencana tindakan yang dilaksanakan, yaitu sebagai berikut.

1) Peneliti mengajukan permohonan ijin terhadap Kepala Sekolah SD Negeri Lengkong dan guru kelas $\mathrm{V}$ serta pihak-pihak yang terkait untuk membantu dan mengarahkan dalam proses penelitian.

2) Menentukan materi pembelajaran Bahasa Indonesia yang akan diajarkan pada siswa sesuai dengan indikator, yaitu mengidentiffikasi unsur intrinsik (tokoh, tema, latar, dan amanat) tentang cerita rakyat. 
3) Menyusun RPP (Rencana Pelaksanaan Pembelajaran) dengan menggunakan media audio

4) Menyiapkan alat-alat yang digunakan dan menunjang pembelajaran

5) Menyusun lembar observasi, yang di dalamnya berisi pengamatan proses pembelajaran yang seharusnya dilakukan oleh guru dan siswa

6) Menyusun lembar penilaian tes menyimak cerita siswa sesuai buku referensi.

\section{b. Pelaksanaan}

Dalam pelaksanaannya, siklus I dilakukan selama satu hari dimulai pada minggu kedua, yaitu pada hari sabtu 12 Agustus 2017. Adapun uraian mengenai pembelajaran yang dilakukan adalah sebagai berikut.

Pertemuan

pertama

dilaksanakan pada hari sabtu, 12 Agustus 2017 pukul 08.00 - 09.30 WIB selama dua jam pelajaran (2 x 35 menit).Pembelajaran dimulai jam ke-2 setelah senam PGRI selesai. Guru masuk kelas pukul 08.00 - 09.30. Guru mengawali pelajaran dengan menunjuk salah satu siswa untuk memimpin doa. Siswa kemudian berdoa, beberapa saat kemudian siswa terlihat ramai. Guru bertanya siapa yang tidak hadir hari ini? Siswa kemudian menjawab hadir semua. Kemudian guru meminta siswa untuk menyiapkan diri menghadapi pembelajaran, namun beberapa siswa tetap ramai. Setelah itu, guru mendekati siswa yang ramai dan mengajak siswa untuk siap dalam pelajaran. Untuk menarik perhatian siswa, guru menyanyikan lagu "Kalau Kau Suka Hati". Siswa terlihat lebih fokus setelah mengikuti apa yang dinyanyikan oleh guru. Guru memberikan petunjuk mengenai pelajaran yang akan dilakukan. Guru dan siswa menamai pelajaran yang dilakukan. Guru kemudian memberikan materi mengenai unsur-unsur cerita. Guru kemudian bertanya kepada siswa apakah siswa sudah paham? Siswa serentak menjawab "sudah!". Guru kemudian menyiapkan siswa untuk menyimak cerita Timun Emas menggunakan 
media audio (jenis rekaman). Akan tetapi cerita yang disimak kurang keras, sehingga siswa diminta untuk merapat kedepan. Terlihat beberapa siswa ramai dan tidak fokus dalam menyimak. Ada juga siswa yang bermain-main dengan alat tulis mereka. Berkalikali guru harus menasihati siswa agar memerhatikan cerita yang disimak. Setelah cerita yang disimak selesai, guru memberikan lembaran soal mengenai cerita pada setiap siswa untuk dikerjakan.

Terlihat ada siswa yang hanya bermain-main. Siswa mengerjakan soal dengan diiringi dengan musik klasik. Setelah selesai, guru meminta salah satu siswa untuk memaparkan hasil mereka, akan tetapi tidak ada siswa yang mau untuk maju kedepan. Sehingga guru menunjuk salah satu siswa untuk maju ke depan. Pada saat siswa yang ditunjuk untuk memaparkan hasilnya ke depan siswa tersebut mengatakan "tidak mau bu yang lain saja" hal ini memiliki maksud bahwa yang harus maju memaparkan hasil ke depan bukan anak tersebut, akan tetapi siswa yang lain. Melihat hal ini, guru tetap menunjuk anak tersebut untuk maju ke depan. Setelah siswa memaparkan hasilnya kemudian siswa yang lain diminta untuk mengutarakan pendapatan atau jawaban yang lain. Oleh karena waktu menunjukkan jam istirahat siswa mulai gaduh dan ingin istirahat untuk jajan. Kemudian guru untuk menghentikan pertemuan pertama. Dan menutup pembelajaran dengan memberikan motivasi kepada siswa untuk semangat belajar.

c. Observasi

Observasi dalam penelitian ini dilakukan untuk mengamati aktivitas siswa dalam pembelajaran menyimak cerita menggunakan media audio. Pada penelitian ini lembar observasi telah disiapkan d. Kegiatan Siswa pada Tindakan Siklus I

Pada awal pertemuan, siswa masih sering berbicara dengan temannya. Ketika guru sedang menjelaskan materi, siswa ada yang menggambar, bermain 
dengan barang-barang di sekitarnya. Ketika guru meminta siswa untuk menyimak cerita rakyat dengan media audio, siswa terlihat diam tetapi masih ada yang ngobrol. Pada saat guru melakukan tanya jawab hanya beberapa siswa yang aktif bertanya dan menjawab.

Tabel 1 Nilai Rerata Kemampuan Menyimak Cerita Pada Siklus I

\begin{tabular}{|c|c|c|c|c|}
\hline \multirow[b]{2}{*}{ No } & \multirow[b]{2}{*}{$\begin{array}{c}\text { Subje } \\
k\end{array}$} & \multicolumn{2}{|c|}{ Frekuensi } & \multirow[b]{2}{*}{$\begin{array}{c}\text { Rerat } \\
\text { a }\end{array}$} \\
\hline & & $\begin{array}{c}\text { Tunta } \\
\mathbf{s}\end{array}$ & $\begin{array}{c}\text { Belu } \\
\text { m } \\
\text { Tunta } \\
\text { s }\end{array}$ & \\
\hline 1 & AR & $\sqrt{ }$ & & \\
\hline 2 & AM & & $\sqrt{ }$ & \\
\hline 3 & $\mathbf{A H}$ & $\sqrt{ }$ & & \\
\hline 4 & Al & - & - & \\
\hline 5 & AF & & $\sqrt{ }$ & \\
\hline 6 & AK & & $\sqrt{ }$ & \\
\hline 7 & DNF & $\sqrt{ }$ & & \\
\hline 8 & DA & $\sqrt{ }$ & & \\
\hline 9 & NO & & $\sqrt{ }$ & \\
\hline 10 & IB & & $\sqrt{ }$ & \\
\hline 11 & IN & $\sqrt{ }$ & & \\
\hline 12 & 10 & $\sqrt{ }$ & & \\
\hline 13 & MEA & & $\sqrt{ }$ & \\
\hline 14 & MIPR & $\sqrt{ }$ & & \\
\hline 15 & MI & & $\sqrt{ }$ & \\
\hline 16 & MR & $\sqrt{ }$ & & \\
\hline 17 & SPP & $\sqrt{ }$ & & \\
\hline \multicolumn{2}{|c|}{ JUMLAH } & & & \\
\hline \multicolumn{2}{|c|}{ RERATA } & & & \\
\hline \multicolumn{2}{|c|}{$\begin{array}{c}\text { PRESENTA } \\
\text { SE (\%) }\end{array}$} & & & \\
\hline
\end{tabular}

\section{KESIMPULAN}

Dari hasil penelitian dan pembahasan yang telah diuraikan pada bab sebelumnya, dapat disimpulkan bahwa proses pembelajaran menyimak cerita menggunakan media audio mengalami perubahan dibandingkan pembelajaran pada pra-penelitian, terutama dalam hal keterlibatan siswa pada setiap kegiatan pembelajaran menyimak cerita. Pada pra-penelitian, partisipasi siswa baik itu motivasi, perhatian, keaktifan dan kesungguhan terhadap pembelajaran menyimak cerita rendah. Kemudian setelah diberikan tindakan berupa penerapan model quantum teaching melalui langkah-langkah ketahuilah bahwa segalanya berbicara, ketahuilah bahwa segalanya bertujuan, sadarilah bahwa pengalaman mendahului penanaman, akuilah setiap usaha, sadarilah bahwa sesuatu yang layak dipelajari layak pula dirayakan, keterlibatan siswa terhadap pembelajaran menyimak cerita meningkat. Secara keseluruhan, pada siklus I jumlah siswa yang terlibat dalam pembelajaran menyimak mencapai kurang dari $65 \%$ jumlah sis 


\section{DAFTAR PUSTAKA}

Jurnal Kreatif Tadulako Online Vol.

3 No. 4ISSN 2354614X

[online]. Tersedia

:http://jurnal.untad.ac.id/jurnal

/index.php/JKTO/article/viewF

ile/3072/2145

Tarigan, H.G. (1994). Menyimak

sebagai suatu Keterampilan

Berbahasa. Bandung:

Angkasa.

Dalman, (2013). Keterampilan

Menyimak. Jakarta: Grapindo.

Ennah, R,. (2009). Media

Pembelajaran. Banjarmasin :

Antasari Pers

Jurnal Pendidikan Guru Sekolah

Dasar Edisi 9 Tahun ke-5

2016 [online]. Tersedia :

http://journal.student.uny.ac.i

d 